\title{
PROVERA METRIJSKIH KARAKTERISTIKA UPITNIKA STILOVA DONOŠENJA KUPOVNIH ODLUKA PRIMENJE- NOG U USLOVIMA SA I BEZ VEZANOSTI ZA PROIZVOD
}

\section{Predrag Okanović' , Dragana Okanović i Nebojša Majstorović}

Odsek za psihologiju, Filozofski fakultet Novi Sad

Osnovni cilj ovog rada je provera faktorske strukture upitnika kupovnih stilova CDMS, kao i testiranje njegove pouzdanosti prilikom primene u uslovima sa $i$ bez vezanosti za proizvod. Teorijsku pozadinu rada čine novije modifikacije istraživanja stilova donošenja kupovnih odluka u okviru pristupa karakteristika kupaca, koji podrazumeva postojanje trajnih crta koje se odnose na donošenje odluka prilikom kupovine. Upitnik CDMS je ovom prilikom prvi put primenjen u Srbiji, u cilju kros-kulturalne validacije. Primenjene su dve verzije instrumenta na dva odvojena uzorka mlade visokoobrazovane populacije - upitnik generalnih kupovnih stilova $(N=200)$ i upitnik vezan za odredeni proizvod ( $N=230)$. Prethodno je odabran proizvod za koji ispitanici vezuju visoku involviranost, odnosno značaj (u pitanju su bile patike), tako da se sadržaj drugog upitnika odnosio na ovaj proizvod.

Studija je dala delimičnu potvrdu salijentnosti faktorske strukture upitnika. Kako u slučaju generalne primene, tako i kod vezanosti za proizvod ekstrahovano je istih pet komponenata: Lojalnost brendu/prodavnici, Perfekcionizam, Svest o brendu, Impulsivnost $i$ Svest o vezi cena-vrednost. Nakon eliminacije odredenog broja stavki iz upitnika, kreirana su dva upitnika: upitnik generalnih stilova donošenja kupovnih odluka sastavljen od 14 stavki i upitnik vezan za patike od 15 stavki. Oba upitnika se sastoje od pet subskala koje reprezentuju ekstrahovane faktore. Zabeležena je niska pouzdanost subskala u oba upitnika, što se delimično može objasniti malim brojem stavki u upitnicima. Osnovne preporuke za dalja istraživanja odnose se na: dodavanje više stavki za postojeće subskale, uključivanje novih faktora u upitnik i primenu upitnika na drugim uzorcima.

Ključne reči: stilovi donošenja kupovnih odluka, upitnik kupovnih stilo$v a$, psihometrijske karakteristike

\footnotetext{
${ }^{1}$ Adresa autora: okanovici@neobee.net
} 


\section{Uvod}

Potreba za izučavanjem stilova donošenja kupovnih odluka raste zajedno sa razvojem tržišta. Sam proces kupovine postaje kompleksniji zahvaljujući povećanom izboru proizvoda, prodavnica, tržnih centara i sl. Kupci postaju preplavljeni informacijama, što sve utiče na opažanje kupovine kao izuzetno složenog i zahtevnog procesa. Upravo iz tih razloga istraživanja donošenjem kupovnih odluka zauzimaju sve značajnije mesto u istraživanju kupovnog ponašanja.

Postoje tri opšteprihvaćena pristupa u izučavanju silova donošenja kupovnih odluka. Prvi je psihografski pristup, kojim se identifikuju one osobine koje su povezane sa određenim kupovnim ponašanjem (Lastovicka, 1982). Drugi je pristup tipologije kupaca, koji podrazumeva klasifikovanje kupaca u pojedine grupe, tj. tipove (Moschis, 1976). Treći pristup je najviše izučavan i najbolje prihvaćen od strane naučne javnosti - pristup karakteristika kupaca. U fokusu ovog gledišta su kognitivne dimenzije koje utiču na donošenje kupovnih odluka. Stil donošenja kupovnih odluka je u okviru pristupa karakteristika kupaca definisan kao: „šematizovana kognitivna orijentacija u kupovini koja trajno dominira kupovnim izborima" (Sproles \& Kendall, 1986; str. 268). U pitanju su trajne, predvidljive crte koje imaju uticaj na kupovinu. Autori navode da ovaj koncept možemo porediti sa konceptom ličnosti koji postoji u psihologiji (eng. 'human personality'), i uslovno ga nazivaju „kupovna ličnost” (engl. 'consumer personality'). Osnovna pretpostavka koja je u osnovi pristupa karakteristika kupaca je da kupci poseduju nekoliko trajnih crta koje se tiču donošenja kupovnih odluka, i koje se kombinuju u stilove kupovine.

Prvi značajniji korak u okviru pristupa karakteristika kupaca napravili su Sproles i Kendalova (Sproles \& Kendall, 1986). Najznačajnije dostignuće ovih autora je upitnik kupovnih stilova CSI ('Consumer Styles Inventory'). Ovaj upitnik originalno sadrži osam faktora (odnosno „mentalnih karakteristika donošenja kupovnih odluka") i doživeo je brojne modifikacije tokom više od 20 godina primene $u$ više svetskih zemalja (npr., Hafstrom, Chae \& Chung, 1992; Lysonski, Durvasula \& Zotos, 1996; Hui \& Siu, 2001; Fan \& Xiao, 1998; Mitchel \& Bates, 1998; Wang, Siu \& Hui, 2004; Cowart \& Goldsmith, 2007). Iako su i pre ovog istraživanja bili prisutni pokušaji da se opiše kupovno ponašanje, pomenuti autori su napravili prvi značajniji korak po pitanju konceptualizacije i merenja kupovnih stilova. Njihova ideja je bila da produkuju instrument koji će služiti praksi, odnosno, koji će „pomoći u identifikovanju stilova kupovine potrošača, njihovoj edukaciji o sopstvenim kupovnim stilovima i savetovanju porodica o upravljanju finansijama" (Sproles \& Kendall, 1986; 
str. 267). Pristup Sprolesa i Kendalove je podrazumevao kreiranje upitnika kupovnih stilova (CSI) i pravljenja profila kupovnog stila (PCS). Na osnovu pregleda marketinške i naučne literature, napravljena je lista od osam fundamentalnih stilova donošenja kupovnih odluka. U pitanju su: perfekcionizam i svest o visokom kvalitetu, svest o brendu i cena-kvalitet, svest o novitetima i modnim trendovima, rekreacijska i hedonistička kupovina, svest o ceni i vezi cena-vrednost, impulsivnost i nepromišljenost, zbunjenost prevelikim izborom i kupovina po navici i lojalnost brendu. Iako je izbor karakteristika kupovnog procesa koje su uključene u upitnik prilično arbitraran, faktorska analiza je potvrdila njihovo postojanje. Istraživanje u kojem su dobijeni ovi faktori je sprovedeno na uzorku od 482 učenika srednjih škola. Upravo to je jedan od nedostataka studije - niska eksterna validnost, odnosno nemogućnost generalizovanja podataka na druge populacije (uslovno rečeno „prosečnog kupca”). Sami autori su naveli da bi upitnik trebalo primeniti, tj. validirati na različitim uzorcima odraslih potrošača.

Kako se interesovanje za ovaj instrument pobudilo i van okvira SAD, javila se i potreba za kros-kulturalnom validacijom upitnika u različitim delovima sveta. Među prvima, Hafstrom, Čae i Čung (Hafstrom, Chae \& Chung, 1992) su primenili CSI na uzorku mladih potrošača u Koreji, u cilju poređenja stilova donošenja kupovnih odluka američke i koreanske mlade populacije. Autori su napravili manju modifikaciju upitnika, usled teškoća u prevodu njegovih šest stavki. Kao uzorak su korišćeni studenti $(\mathrm{N}=310)$, što uz isti teorijski i metodoliški okvir ide u prilog tome da se rezultati ove dve studije mogu porediti. Koreanska studija je potvrdila postojanje sedam faktora, dok faktor „svest o novitetima i modnim trendovima" nije identifikovan. S druge strane, na koreanskom uzorku je identifikovan faktor „štednja vremena i energije”, koji uključuje ponašanja poput konsultovanja časopisa i poređenja reklama pre nego što se krene u kupovinu. Najvažniji zaključak koji su izveli autori istraživanja je da postoje velike sličnosti sa rezultatima originalne studije koja je sprovedena u Americi. Na osnovu toga se javlja „oprezni optimizam da CSI ima elemente konstruktne validnosti i potencijal da se koristi na međunarodnom nivou" (Hafstrom, Chae, \& Chung, 1992; str. 157).

Nekoliko godina kasnije, ponovo sa ciljem kros-kulturne validacije CSI upitnika, sprovedeno je istraživanje na kineskom uzorku (Fan \& Xiao, 1998). Ponovo je korišćen uzorak studenata, radi mogućnosti poređenja sa prethodnim studijama. Autori su ovaj put krenuli od modifikovanog koncepta stilova donošenja kupovnih odluka, predloživši model od sedam faktora. Faktorskom analizom je identifikovano pet faktora, a u pitanju su: Svest o brendu, Svest o vremenu, Svest o kvalitetu, Svest o ceni i Korisnost informacija. S obzirom na 
drugačiji teorijski okvir, a posledično i modifikovani upitnik, poređenje ovog sa prethodnim istraživanjima je prilično nezahvalno. Ipak, jasno je da postoji velika sličnost u faktorima koji su dobijeni na kineskom uzorku sa onima koji su prethodno dobijeni u Americi i Koreji. Ipak, tri faktora nisu identifikovana na kineskom uzorku. Nekoliko razloga leži u osnovi ovih razlika (Fan \& Xiao, 1998). Pre svega, problem prevoda i implicitnih značenja dovode do različitih shvatanja pojedinih stavki kod ispitanika iz različitih govornih područja. Drugo, tržišta robe široke potrošnje su veoma različita u ove tri zemlje, što dovodi do pojave različitih stilova donošenja kupovnih odluka. Takođe, stepen ekonomske razvijenosti zemalja utiče na kupovnu moć potrošača, što u velikoj meri određuje njihov stil kupovine.

Upravo se ekonomska razvijenost zemalja našla u fokusu narednog istraživanja sa CSI upitnikom, koje je grupa autora sprovela u četiri različite države (Lysonski, Durvasula, \& Zotos, 1996). Krenuvši od ideje da su stilovi donošenja kupovnih odluka nezavisni od kulture (analogno crtama ličnosti), autori su istovremeno primenili CSI na četiri studentska uzorka u Grčkoj, Indiji, Novom Zelandu i SAD. Njihov osnovni nalaz je da je CSI mnogo primenljiviji (metodološkim rečnikom rečeno: ima bolja psihometrijska svojstva u smislu jasnije faktorske strukture i više pouzdanosti) u razvijenim zemljama (SAD i Novi Zeland), nego u zemljama koje se razvijaju (Grčka i Indija). Autori upravo u stepenu razvijenosti zemalja i razlikama u strukturi tržišta vide veliku prepreku za internacionalnu validaciju upitnika. CSI praktično ne može biti primenjen u zemljama gde ne postoji konkurencija na tržištu i gde je kupovni izbor limitiran, dok se u visoko razvijenim zemljama očekuje psihometrijska podrška upitniku. Autori predlažu jedan od načina da se ovaj problem prevaziđe - koncipiranjem kraće verzije upitnika sa manje dimenzija, koji ima veću šansu da dostigne kros-kulturalnu validaciju.

Mičel i Bejtsova (Mitchel \& Bates, 1998) su prilikom primene CSI u Velikoj Britaniji krenuli od pretpostavke da su stilovi donošenja kupovnih odluka zavisni od kulture. S obzirom da su u prethodnim studijama istraživači dobijali samo delimično preklapanje rezultata, pretpostavili su da će se to desiti i u njihovoj studiji. Primenivši CSI na studentskom uzorku (401 ispitanik), dobili su potvrdu za svih osam faktora originalne studije, ali i dva nova faktora. Prvi od njih je „Štednja vremena i energije”, koji je ranije uočen na koreanskom uzorku (Hafstrom, Chae, \& Chung , 1992), a drugi je „Lojalnost prodavnici“, jedinstven za britanski uzorak. Autori ove studije među prvima veoma jasno izražavaju sumnju da je kros-kulturalna validacija upitnika CSI uopšte moguća. Nakon više od decenije istraživanja u ovoj oblasti ostaje nejasno da li su razlike, koje su dobijene $u$ do tada objavljenim istraživanjima, posledica istin- 
skih razlika koje postoje u populacijama, problema sa merenjem ovog fenomena ili čak interpretacijom nalaza.

Nakon 2000. godine nekoliko studija je prebacilo fokus sa studenata na odrasle potrošače. Pionirski korak $\mathrm{u}$ tom smislu je napravljen u Kini (Hui \& Siu, 2001). Prikupljanje podataka je vršeno u tržnim centrima, na uzorku žena (370), i bilo je vezano za tržište kozmetičkih proizvoda. Dakle, iako su izašli iz okvira studentskog uzorka, i ovde su autori jasno ograničili dobijene rezultate na određeni segment potrošačke populacije. Istraživanje je rezultiralo upitnikom sa 29 stavki, koji je pokazao osmofaktorsku strukturu. Rezultati su slični originalnoj studiji, kao i studijama koje su usledile nakon nje (Fan \& Xiao, 1998; Hafstrom, Chae, \& Chung, 1992; Lysonski, Durvasula, \& Zotos, 1996). Četiri faktora su se pokazala zajedničkim za američke i kineske potrošače: Perfekcionizam, Svest o novitetima i modnim trendovima, Svest o brendu i Rekreacijska i hedonistička kupovina. Stavke na preostala četiri faktora nisu dosledno raspoređene u ova dva uzorka, odnosno imaju različite korelacije sa faktorima. Opšti zaključak je, kao i u većini studija sa CSI upitnikom, da je njegova faktorska struktura delimično potvrđena, i da su potrebne dalje modifikacije kako bi dostigao kros-kulturalnu validaciju.

Istraživanja na populaciji odraslih potrošača su potom nastavljena u Nemačkoj. Volš, Mičel i Henih-Turau (Walsh, Mitchell, \& Hennig-Thurau, 2001) su sproveli istraživanje na 455 potrošača u tržnim centrima u Nemačkoj. Primenjen je upitnik CSI sa 38 stavki (izbačene su dve stavke iz originalne verzije usled teškoća sa prevodom). U poređenju sa originalnom studijom (Sproles \& Kendall, 1986), rezultati su dali potvrdu za šest od osam faktora (Svest o brendu, Perfekcionizam, Rekreacijska i hedonistička kupovina, Zbunjenost prevelikim izborom, Impulsivnost i Svest o novitetima i modnim trendovima). Kao sedmi faktor je identifikovano „Traganje za raznovrsnošću”, kao zamena za dva faktora iz originalnog modela CSI (Lojalnost brendu i Odnos cenavrednost). Ponovo je struktura CSI upitnika samo delimično potvrđena, a teza da je upitnik osetljiv na kulturne razlike dobija još jednu potvrdu (s obzirom da je u Nemačkoj dobijen novi faktor, slično kao i u drugim zemljama).

Isti autori su nastavili istraživanja sa CSI upitnikom, i u narednoj studiji su pokušali da utvrde razlike među polovima s obzirom na stilove donošenja kupovnih odluka (Mitchell \& Walsh, 2004). Istraživanje je sprovedeno u Nemačkoj, na uzorku od 358 odraslih ispitanika. Interesantno je da je na poduzorku žena potvrđena prethodno identifikovana sedmofaktorska struktura, dok je na muškom poduzorku potvrđeno tek četiri od navedenih sedam faktora (Svest o brendu, Perfekcionizam, Zbunjenost prevelikim izborom i Impulsivnost). Po- 
red toga, kod muškaraca se javilo dodatnih pet faktora koji nisu uočeni u ranijim istraživanjima.

Dakle, konstruktna validnost upitnika je potvrđena za žene, ali ne i za muškarce. To otvara potpuno novu dimenziju istraživanja, s obzirom da je uočeno da postoje razlike među polovima kada su u pitanju stilovi donošenja kupovnih odluka. Iste godine je sprovedeno istraživanje na uzorku muških potrošača u Britaniji (Bakewell \& Mitchell, 2004). Autori su primenili CSI upitnik na uzorku 245 isključivo muških studenata (pod obrazloženjem da su muškarci bili zapostavljeni u prethodnim istraživanjima stilova kupovine). Identifikovana je dvanaeastofaktorska struktura: svih osam originalnih stilova donošenja kupovnih odluka, plus četiri nova. Osnovni zaključak je da su muškarci po ovom svojstvu drugačiji od žena, i da bi bilo neophodno kreirati posebne upitnike za ove dve populacije.

Pregledom prvih 20 godina primene upitnika CSI stiče se utisak da se slika o stilovima donošenja kupovnih odluka neprestano komplikuje. Iako je možda bilo za očekivati da će različita istraživanja sva ići ka jednom toku i jedinstvenom rešenju, sumnja u sam konstrukt stilova donošenja kupovnih odluka raste sa svakim novim nalazom. Iako su rezultati svih studija donekle slični, stiče se utisak da je teško očekivati kros-kulturalnu validaciju upitnika. Sve češće se javlja ideja da je potrebno napraviti specijalizovane upitnike za posebne zemlje (ili bar kategorije zemalja s obzirom na ekonomsku razvijenost), uzrasne kategorije, kategorije proizvoda, muškarce i žene itd.

Upravo sa tog stanovišta su krenuli Bauer, Sauer i Bekerova, koji su u svojoj studiji izrazili sumnju da CSI može da se primenjuje nezavisno od proizvoda (Bauer, Sauer, \& Becker, 2006). Njihova pretpostavka je da stilovi donošenja kupovnih odluka nisu isti za sve kategorije proizvoda, što predstavlja novinu u odnosu na pređašnja istraživanja gde se podrazumevalo postojanje jedinstvenih kupovnih stilova nezavisno od proizvoda. Dodatno, autori ove studije smatraju da pored kategorije proizvoda, treba uzeti u obzir i stepen involviranosti u proizvod, odnosno, značaj proizvoda za pojedinca. Nakon negativnog iskustva sa primenom CSI, autori su krenuli u revidiranje konstrukta stilova donošenja kupovnih odluka. Njihov model je pretpostavljao sedam faktora. Pet su preuzeti iz originalnog CSI (Perfekcionizam, Svest o brendu, Svest o vezi cena-vrednost, Lojalnost brendu/prodavnici i Spontanost), dok su pretpostavljena dva nova faktora: Inovativnost i Traganje za raznovrsnošću. Tri faktora su eliminisana (Svest o novitetima i modnim trendovima, Rekreacijska i hedonistička kupovina i Zbunjenost prevelikim izborom). Takva pretpostavka je rezultirala novonastalim upitnikom sa 32 stavke, koji je primenjen na studentskim uzorcima u Nemačkoj i Velikoj Britaniji. Još jedna od novina ove 
studije je primena upitnika vezano za određeni proizvod. Autori su izabrali dva proizvoda: jedan koji je pokazao visoku involviranost kod ispitanika i jedan sa niskom involviranošću. Pod involviranošću se podrazumeva značaj i vrednost proizvoda za self potrošača, kao i zadovoljstvo koje on izaziva kod potrošača usled posedovanja i korišćenja.

Rezultati nisu potvrdili sedmofaktorsku strukturu. Kod proizvoda sa niskom involviranošću faktorska analiza nije ekstrahovala interpretabilnu strukturu, dok su kod proizvoda sa visokom involviranošću analizom izdvojena četiri faktora: Lojalnost brendu/prodavnici, Spontanost, Svest o vezi cena-vrednost i Traganje za raznolikošću. Treba naglasiti da su u prvi faktor, pored lojalnosti, sadržinski uključeni i Perfekcionizam i Svest o brendu. Autori su kao svoj najznačajniji nalaz izdvojili to da stilovi donošenja kupovnih odluka nisu nezavisni od proizvoda, i da su pored toga zavisni od involviranosti u proizvod. Takav nalaz navodi na zaključak da je potrebno razviti posebne verzije upitnika za različite kategorije proizvoda (različitih nivoa involviranosti). Čini se da je ovakav pristup precizniji i bliži realnosti, i da može ukazati na dalji pravac istraživanja u ovoj oblasti.

Generalni zaključak pregleda svih dosadašnjih istraživanja može biti da jedinstveno rešenje za strukturu stilova donošenja kupovnih odluka za sada ne postoji. Od preko deset studija koje su se bavile validacijom upitnika CSI, ne postoje dve sa istim rezultatima. Kada se pogledaju sličnosti koje postoje u rezultatima ovih studija, nekoliko faktora pokazuju stabilnost (Perfekcionizam, Svest o brendu, Zbunjenost prevelikim izborom i Rekreacijska i hedonistička kupovina), dok se neki sporadično pojavljuju (Svest o novitetima i modnim trendovima, Impulsivnost, Svest o vezi cena-vrednost i Lojalnost brendu).

Više objašnjenja može ležati u osnovi ovih razlika. S jedne strane stoje metodološki problemi, kao što su: uzorci koji su korišćeni (različite kategorije potrošača: učenici, studenti, odrasli potrošači, isključivo žene ili muškarci), nemogućnost preciznog prevođenja stavki, razlike $u$ analiziranju rezultata i sl. Vrlo je verovatno da se deo ovih razlika može objasniti navedenim metodološkim nedoslednostima. Ipak, verovatnije objašnjenje leži u samom konstruktu stilova donošenja kupovnih odluka, odnosno da taj fenomen nije moguće kros-kulturalno validirati. U poslednjih nekoliko godina sve je dominantnija ideja da je nemoguće dostići univerzalne mere koje bi pokrile sav varijetet te pojave, i da rešenje treba tražiti u specifičnim instrumentima za pojedine kulture, kategorije proizvoda, grupe potrošača i sl. 


\section{Problem istraživanja}

Osnovni problem ovog rada je provera faktorske strukture upitnika kupovnih stilova CDMS (Bauer, Sauer, \& Becker, 2006), kao i testiranje njegove pouzdanosti prilikom primene u uslovima sa i bez vezanosti za proizvod. Teorijsku pozadinu rada čine istraživanja stilova donošenja kupovnih odluka u okviru pristupa karakteristika kupaca, koji podrazumeva postojanje trajnih crta koje se odnose na donošenje odluka prilikom kupovine (Sproles \& Kendall, 1986). Ovaj rad se najviše bazira na novijim modifikacijama prvobitnih nalaza Sprolesa i Kendalove (Bauer, Sauer, \& Becker, 2006). Modifikacije su nastale u samom konstruktu, a osnovni razlog za to je nejasan teorijski okvir, koji je za posledicu imao prilično arbitraran izbor karakteristika kupovnog procesa koje su uključene u upitnik, što je rezultiralo nejasnom faktorskom strukturom i niskom pouzdanošću. Izmene su nastale i u samoj primeni - novonastali upitnik kupovnih stilova CDMS pokazao je jasniju faktorsku strukturu kada se primenjuje vezano za određeni proizvod koji je značajan za potrošača (visoka involviranost) a ne za generalno kupovno ponašanje. Upitnik CDMS je primenjen u uslovima sa i bez vezanosti za proizvod.

U Srbiji se autori do sada nisu bavili problemom stilova donošenja kupovnih odluka, tako da naše istraživanje predstavlja pionirski poduhvat u tom smislu. Prolem involviranosti je bio tema jednog istraživanja objavljenog kod nas, $u$ kojem su autori proveravali psihometrijske karakteristike dva upitnika involviranosti (Petrović i Kovačević, 1996).

\section{Metod}

\section{Instrumenti}

Upitnik involviranosti za proizvode. Upitnik je konstruisan za potrebe ovog istraživanja, a kao osnova je poslužio upitnik involviranosti koji su konstruisali Bauer i saradnici, koji su involviranost (značaj) proizvoda definisali kao percipirani značaj proizvoda baziran na unutrašnjim potrebama, vrednostima i interesima (Bauer, Sauer, \& Becker, 2006). Korišćeni upitnik prati faktorsku strukturu pomenutog instrumenta, sa tri identifikovana faktora: važnost, zadovoljstvo i značaj proizvoda za self potrošača. Za potrebe ovog istraživanja, pomenuti upitnik je zbog pojednostavljivanja redukovan sa 12 na 6 stavki, tako da je svaki faktor reprezentovan putem dve stavke (odabrano je 6 stavki koje su u pomenutom istraživanju pokazale najvišu korelaciju sa faktorima). Uz svaku stavku je pridružena petostepena Likertova skala. U upitniku je po- 
nuđeno pet proizvoda za koje su ispitanici procenjivali involviranost: patike, cipele, ručni sat, mobilni telefon i duks/džemper, a postojala je i mogućnost samostalnog upisivanja naziva proizvoda. Za svaki od ovih šest slučajeva vezan je pomenuti upitnik od šest stavki, tako da su ispitanici popunjavali šest posebnih mini-upitnika u okviru ovog instrumenta.

Generalni upitnik kupovnih stilova (CDMS.) U ovom istraživanju upitnik CDMS ("Consumer Decision-Making Styles") je primenjen u originalnoj verziji do koje su došli Bauer i saradnici (2006), modifikacijom upitnika CSI (Sproles \& Kendall, 1986). CDMS je ovom prilikom primenjen kao generalni upitnik kupovnih stilova, nevezano za određeni proizvod. Upitnik se sastoji od 21 stavke, sa petostepenom Likertovom skalom. Odabrani upitnik, kako je ranije izloženo, predstavlja pokušaj da se prevaziđe problem nejasnog teorijskog koncepta na kojem je počivao CSI. Upravo zato smo se odlučili da primenimo CDMS upitnik a ne CSI, koji je dokazano problematičan sa stanovišta faktorske strukture.

Upitnik kupovnih stilova (CDMS) vezan za proizvod. CDMS upitnik je primenjen i u situaciji kada se odnosi na određeni proizvod (koji je odabran na osnovu inicijalnog ispitivanja involviranosti; u ovom slučaju to su „patike”). Upitnik je identičan gore pomenutom, uz napomenu da se sve stavke odnose na ponašanja u vezi sa kupovinom patika. Dodatno je uvršteno i pitanje "koliko značaja pridajete patikama kao proizvodu" (sa petostepenom skalom), kako bi se dodatno ispitala involviranost, u cilju eventualne eliminacije onih ispitanika koji pokazuju nizak stepen involviranosti za izabrani proizvod.

\section{Uzorak i procedura istraživanja}

Populacija koja je u fokusu ovog istraživanja su mladi 18-30 godina, pretežno studenti i mladi visokoobrazovani ljudi. Ovakav uzorak se poklapa sa ranijim istraživanjem na koje se rad oslanja (Bauer, Sauer, \& Becker, 2006), tako da je moguće izvršiti poređenje sa nalazima dobijenim na osnovu iste metodologije u Velikoj Britaniji i Nemačkoj. Inicijalno ispitivanje involviranosti vezano za proizvode izvršeno je na uzorku od 50 ispitanika, na koncertu „Super svima”, koji je održan 25. maja 2008. u Novom Sadu. Prikupljanje podataka je sprovelo dvoje obučenih anketara, a vršeno je tako što su ankete deljene posetiocima koncerta. Ispitanici su ih samostalno popunjavali, uz prethodno upoznavanje sa svrhom istraživanja. $\mathrm{Na}$ osnovu podataka o involviranosti, od pet ponuđenih, odabran je jedan proizvod za koji će biti vezan upitnik kupovnih stilova CDMS (u pitanju su „patike”). Centralni deo istraživanja je sproveden na mu- 
zičkom festivalu EXIT u Novom Sadu, u periodu 10-13. jul 2008. Sprovedena je primena upitnika kupovnih stilova CDMS na dva nezavisna uzorka: vezanog za prethodno odabrani proizvod $(\mathrm{N}=230)$ i generalnog upitnika kupovnih stilova $(\mathrm{N}=200)$. Postupak prikupljanja podataka je identičan kao kod ispitivanja involviranosti - anketari su vršili deljenje anketa posetiocima festivala, a ispitanici su ih samostalno popunjavali prilikom ulaska na koncert.

\section{Rezultati}

\section{Ispitivanje involviranosti}

Ispitivanje involviranosti je sprovedeno sa ciljem da se odabere jedna kategorija proizvoda za koju će biti vezana primena upitnika CDMS. Ispitanici su popunjavali šest mini-upitnika involviranosti (svaki sa po šest stavki) sa ponuđenim kategorijama proizvoda. Izbor proizvoda je vršen na osnovu skorova na upitnicima. Najviši nivo involviranosti zabeležen je kod proizvoda koje su ispitanici sami navodili (Tabela 1). S obzirom da su ispitanici navodili veliki broj različitih proizvoda (ukupno 30), od kojih ni jedan nije naveden više od pet puta, ova kategorija nije upotrebljena u daljem istraživanju.

Tabela 1. Rezultati ispitivanja involviranosti

\begin{tabular}{lcccc}
\hline Kategorija proizvoda & Aritmetička sredina & SD & Minimum & Maksimum \\
\hline patike & 21.18 & 3.98 & 11 & 28 \\
duks/džemper & 20.16 & 5.38 & 6 & 27 \\
mobilni telefon & 19.98 & 6.15 & 6 & 30 \\
ručni sat & 15.40 & 7.41 & 6 & 30 \\
cipele & 15.00 & 5.62 & 6 & 26 \\
(dodatni proizvodi) & 25.82 & 4.29 & 10 & 30 \\
\hline
\end{tabular}

Od ponuđenih pet proizvoda, najvišu involviranost (izraženo najvišim skorom na upitniku i najnižom standardnom devijacijom) pokazala je kategorija proizvoda "patike”. Na osnovu tih podataka, patike su odabrane kao proizvod za koji će biti vezan upitnik CDMS. Zanimljivo je da su patike bile uključene kao objekat merenja i u ranije navedenom istraživanju involviranosti na našoj populaciji, pri čemu je upitnik involviranosti za taj proizvod dao jasnu faktorsku strukturu (Petrović i Kovačević, 1996). 


\section{Faktorska analiza upitnika CDMS}

Upitnik kupovnih stilova CDMS je primenjen na dva nezavisna uzorka: na jednom je primenjen generalni upitnik kupovnih stilova, a na drugom upitnik vezan za kupovinu patika. U skladu sa tim, sprovedene su dve nezavisne faktorske analize. Korišćena je metoda glavnih komponenti, uz kosouglu rotaciju (Promax). Ranija istraživanja su takođe koristila ortogonalnu rotaciju Varimax (Sproles \& Kendall, 1986; Mitchel \& Bates, 1998; Wang, Siu, \& Hui, 2004; Bauer, Sauer, \& Becker, 2006).

U oba slučaja je nakon sprovođenja faktorizacije na kompletnom upitniku (21 stavka) dobijena nejasna faktorska struktura. U cilju dobijanja interpretabilne faktorske strukture sledeći korak je podrazumevao eliminisanje stavki koje nepovoljno utiču na interpretabilnost strukture, odnosno učestvuju u formiranju više faktora ili samostalno formiraju neinterpretabilan faktor. Na taj način nije eliminisan nijedan ceo faktor, već su u pitanju stavke koje učestvuju u formiranju ekstrahovanih faktora. Njihovim izostavljanjem samo je umanjen broj stavki u dobijenim faktorima. Kao rezultat dobijena su dva upitnika sa manjim brojem stavki od onih koji su primenjeni, sa jasnom faktorskom strukturom. U nastavku slede rezultati za dva slučaja primene CDMS: kao generalnih stilova kupovine i vezano za patike.

\section{Faktorska struktura CDMS - generalni}

Faktorizacijom kompletne verzije upitnika CDMS-generalni dobijena je nejasna struktura sa osam faktora. Kako bi se dobila interpretabilna faktorska struktura, usledila je eliminacija sedam stavki. Na taj način je dobijena interpretabilna petofaktorska struktura, kojom je objašnjeno $55,5 \%$ varijanse generalnih stilova donošenja kupovnih odluka. Izbor pet faktora je izvršen na osnovu Kajzer-Gutmanovog kriterijuma i Scree dijagrama. Pouzdanost upitnika u celini izražena Kronbahovom alfom je niska - 0,62.

Tabela 2. Procenat objašnjene varijanse, CDMS-generalni

\begin{tabular}{cccc}
\hline \multirow{2}{*}{ Faktor } & \multicolumn{3}{c}{ Svojstvene vrednosti } \\
\cline { 2 - 4 } & $\lambda$ & \% varijanse & Kumulativni \% \\
\hline 1 & 2.46 & 17.55 & 17.55 \\
2 & 1.57 & 11.19 & 28.74 \\
3 & 1.34 & 9.54 & 38.29 \\
4 & 1.25 & 8.91 & 47.20 \\
5 & 1.17 & 8.33 & 55.53 \\
\hline
\end{tabular}




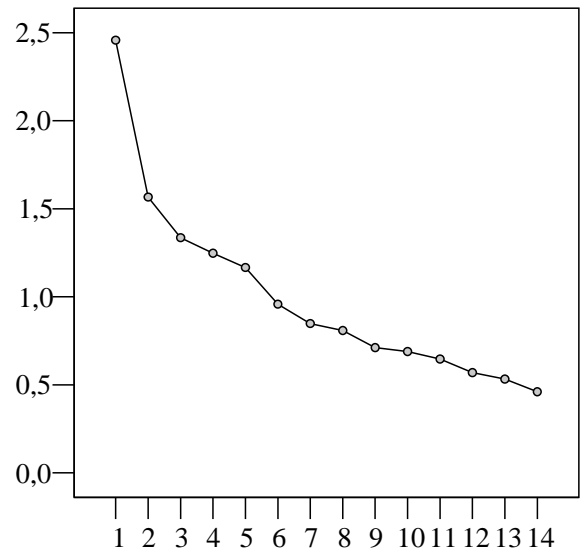

Slika 1. Scree dijagram faktorske analize CDMS - generalni

Tabela 3. Matrica sklopa faktora upitnika CDMS-generalni

\begin{tabular}{|c|c|c|c|c|c|}
\hline Stavke & 1 & 2 & 3 & 4 & 5 \\
\hline $\begin{array}{l}\text { Kada jednom izaberem prodavnicu gde kupujem, } \\
\text { radije kupujem tamo nego na drugim mestima. }\end{array}$ & .86 & & & & \\
\hline $\begin{array}{l}\text { Kada jednom pronađem marku koja mi se do- } \\
\text { pada, stalno je kupujem. }\end{array}$ & .77 & & & & \\
\hline $\begin{array}{l}\text { Imam omiljene marke proizvoda koje uvek ku- } \\
\text { pujem. }\end{array}$ & .51 & & & & \\
\hline $\begin{array}{l}\text { Kada kupujem uvek odlazim u istu(e) prodavni- } \\
\text { cu(e). }\end{array}$ & .49 & & & & \\
\hline $\begin{array}{l}\text { Obično se veoma trudim da odaberem najbolji } \\
\text { proizvod. }\end{array}$ & & .74 & & & \\
\hline $\begin{array}{l}\text { Vodim računa da dobijem najbolji mogući kva- } \\
\text { litet proizvoda za njegovu cenu. }\end{array}$ & & .72 & -.34 & & \\
\hline $\begin{array}{l}\text { Moji standardi i očekivanja u vezi sa proizvo- } \\
\text { dom koji nameravam da kupim su vrlo visoki. }\end{array}$ & & .70 & & & \\
\hline Obično kupujem najnovije proizvode na tržištu. & & & .80 & & \\
\hline Obično biram skuplje marke proizvoda (brend). & & & .76 & & \\
\hline $\begin{array}{l}\text { Trebalo bi duže da razmišljam pre nego što done- } \\
\text { sem odluku o kupovini određenog proizvoda. }\end{array}$ & & & & .80 & \\
\hline Trebalo bi da pažljivije planiram kupovinu. & & & & .72 & \\
\hline Često tragam za rasprodajama. & & & & & .69 \\
\hline $\begin{array}{l}\text { Mislim da se različite marke kod proizvoda iste } \\
\text { vrste ne razlikuju po kvalitetu. }\end{array}$ & & & & & .69 \\
\hline $\begin{array}{l}\text { Obično uštedim dosta novca cenkajući se sa } \\
\text { prodavcem. }\end{array}$ & & & & & .51 \\
\hline
\end{tabular}


Prvi faktor izdvojen iz upitnika CDMS-generalni objašnjava $17.6 \%$ varijanse rezultata $(\alpha=0,61)$. Na osnovu sadržinske analize, ovaj faktor se može definisati kao LOJALNOST BRENDU/PRODAVNICI. Iako se po nazivu poklapa sa prethodnim istraživanjem na upitniku CDMS (Bauer, Sauer, \& Becker, 2006; str. 349), sadržaj ovog faktora je mnogo „čistiji” od onog kojeg su dobili pomenuti autori. Naime, u pomenutoj studiji Lojalnost brendu/prodavnici obuhvata i stavke koje sadržinski pripadaju faktorima Perfekcionizam i Svest o brendu, koji su u ovom istraživanju razdvojeni. Drugi izdvojeni faktor objašnjava $11,2 \%$ varijanse rezultata $(\alpha=0,58)$. Na osnovu sadržinske analize, ovaj faktor se može definisati kao PERFEKCIONIZAM. To je jedan od faktora koji se sreće u svim objavljenim studijama na upitniku CSI (Sproles \& Kendall, 1986; Hui \& Siu, 2001; Bakewell \& Mitchell, 2004). Treći izdvojeni faktor objašnjava $9,54 \%$ varijanse rezultata $(\alpha=0,47)$. Sadržaj stavki koje ga definišu odnose se uglavnom na svest o markama proizvoda, te je stoga ovaj faktor nazvan SVEST O BRENDU. Ovaj faktor se takođe neizostavno pojavljivao u dosadašnjim studijama stilova donošenja kupovnih odluka. Četvrti izdvojeni faktor objašnjava $8,91 \%$ varijanse rezultata $(\alpha=0,45)$. Ovaj faktor je nazvan IMPULSIVNOST, i poklapa se sa faktorom Spontanost kojeg su identifikovali Bauer i saradnici (Bauer, Sauer, \& Becker, 2006). S obzirom da je u prethodnim istraživanjima dominirao termin Impulsivnost, upotrebljen je upravo taj termin. Peti faktor objašnjava $8,33 \%$ varijanse rezultata $(\alpha=0,31)$. Na osnovu sadržinske analize, ovaj faktor se može definisati kao SVEST O VEZI CENAVREDNOST. Sadržaj faktora, odnosno stavke koje ga definišu, u potpunosti odgovaraju nalazima prethodne studije sa upitnikom CDMS (Bauer, Sauer, \& Becker, 2006).

Kada se posmatra pouzdanost subskala koje predstavljaju faktore, može se konstatovati prilično niska pouzdanost za sve subskale. Pouzdanost je izražena putem Kronbahove alfe kao pokazatelja interne konzistentnosti, tako što su $\mathrm{u}$ analizu uključene stavke koje formiraju faktor. Osnovni uzrok niske pouzdanosti nalazi se i u malom broju stavki koje formiraju navedene faktore (dve do četiri stavke).

Posmatrajući međusobne korelacije pet ekstrahovanih faktora, uočljivo je grupisanje tri prva faktora: Lojalnost brendu/prodavnici, Perfekcionizam i Svest o brendu (Tabela 4). To se poklapa sa nalazom studije Bauera i saradnika (Bauer, Sauer, \& Becker, 2006), gde su ova tri faktora svrstana u jedan (Lojalnost brendu/prodavnici). Iako se sadržinski takvo spajanje može osporiti, korelaciona analiza ukazuje na to da ovi faktori ipak dele zajedničku varijansu i da kognitivni mehanizmi koji stoje u njihovoj pozadini nisu potpuno nezavi- 
sni. Preostala dva faktora nisu pokazali povezanost sa ostalima, što ukazuje na njihovu nezavisnost.

Tabela 4. Korelacije medu faktorima (CDMS-generalni)

\begin{tabular}{lccccc}
\hline \multicolumn{1}{c}{ Faktori } & $\begin{array}{c}\text { Lojal. bren- } \\
\text { du } \\
\text { /prodavnici }\end{array}$ & Perfekc. & $\begin{array}{c}\text { Svest o } \\
\text { brendu }\end{array}$ & Impulsiv. & $\begin{array}{c}\text { Svest o vezi } \\
\text { cena- } \\
\text { vrednost }\end{array}$ \\
\hline $\begin{array}{l}\text { Lojalnost brendu } \\
\text { /prodavnici }\end{array}$ & & & & \\
$\begin{array}{l}\text { Perfekcionizam } \\
\text { Svest o brendu }\end{array}$ & $\mathbf{. 2 1 ( . 0 0 )}$ & & & \\
$\begin{array}{l}\text { Impulsivnost } \\
\text { Svest o vezi }\end{array}$ & $.07(.00)$ & $\mathbf{. 1 8 ( . 0 1 )}$ & $.01(.88)$ & -.09 & \\
cena-vrednost & $-.03(.64)$ & $-.08(.29)$ & $.00(.98)$ & $.09(.22)$ & \\
\hline
\end{tabular}

\section{Faktorska struktura CDMS - patike}

Kako je napomenuto u odeljku o instrumentima istraživanja, u upitnik vezan za patike uvršteno i pitanje „Koliko značaja pridajete patikama kao proizvodu?" sa pridruženom petostepenom skalom. Ovo pitanje je poslužilo kao kriterijum eliminacije onih ispitanika koji pokazuju nizak stepen involviranosti za navedeni proizvod. Na taj način su iz uzorka ispitanika koji su popunili ovaj upitnik izbačeni oni koji su na postavljeno pitanje odgovorili sa 1 ili 2 . U konačnu analizu je uvršteno 193 ispitanika (od ukupno 230).

Faktorizacijom kompletne verzije upitnika CDMS-patike dobijena je nejasna struktura sa sedam faktora. Kako bi se dobila interpretabilna faktorska struktura, usledila je eliminacija šest stavki. Na taj način je dobijena interpretabilna petofaktrska struktura, kojom je objašnjeno $56,6 \%$ varijanse stilova donošenja kupovnih odluka vezanih za patike. Izbor pet faktora je izvršen na osnovu Kajzer-Gutmanovog kriterijuma i Scree dijagrama. Pozdanost upitnika u celini izražena Kronbahovom alfom je niska - 0,56. 
Tabela 5. Procenat objašnjene varijanse, CDMS-patike

\begin{tabular}{cccc}
\hline \multirow{2}{*}{ Faktor } & \multicolumn{3}{c}{ Svojstvene vrednosti } \\
\cline { 2 - 4 } & $\lambda$ & \% varijanse & Kumulativni \% \\
\hline 1 & 2.60 & 17.38 & 17.38 \\
2 & 1.76 & 11.73 & 29.12 \\
3 & 1.58 & 10.54 & 39.66 \\
4 & 1.31 & 8.74 & 48.41 \\
5 & 1.22 & 8.19 & 56.60 \\
\hline
\end{tabular}

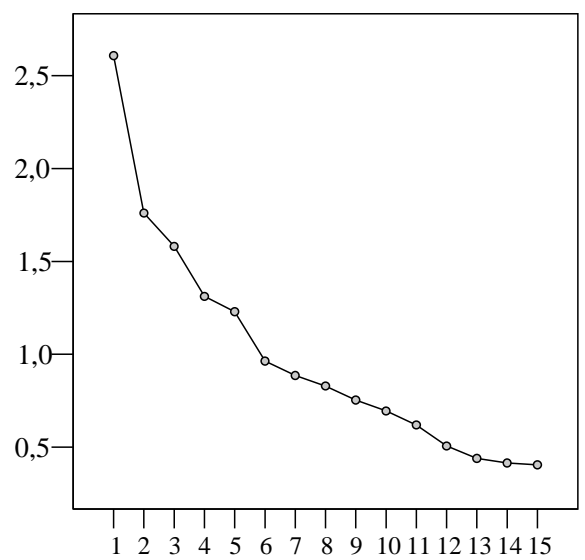

Slika 2. Scree dijagram faktorske analize CDMS-patike

Tabela 6. Matrica sklopa faktora upitnika CDMS-patike

\begin{tabular}{llllll}
\hline Stavke & 1 & 2 & 3 & 4 & 5 \\
\hline $\begin{array}{l}\text { Kada jednom izaberem prodavnicu gde kupu- } \\
\text { jem, radije kupujem tamo nego na drugim }\end{array}$ & .80 & & & \\
mestima. & & & \\
Kada kupujem uvek odlazim u istu(e) prodav- & .77 & \\
nicu(e). \\
Kada jednom pronađem marku koja mi se do- \\
pada, stalno je kupujem. \\
$\begin{array}{l}\text { Imam omiljene marke proizvoda koje uvek } \\
\text { kupujem. }\end{array}$ \\
$\begin{array}{l}\text { Zaista uživam u isprobavanju različitih proiz- } \\
\text {. }\end{array}$
\end{tabular}


voda i marki.

Obično kupujem najnovije proizvode na tržištu.

Obično biram skuplje marke proizvoda (brend).

Obično se veoma trudim da odaberem najbolji proizvod.

Vodim računa da dobijem najbolji mogući kvalitet proizvoda za njegovu cenu.

Moji standardi i očekivanja u vezi sa proizvodom koji nameravam da kupim su vrlo visoki.

Mislim da se različite marke kod proizvoda iste vrste ne razlikuju po kvalitetu.

Trebalo bi duže da razmišljam pre nego što donesem odluku o kupovini određenog proizvoda.

Kupujem brzo tako što kupim prvi proizvod koji mi se čini dovoljno dobrim.

Faktorizacijom upitnika CDMS-patike izdvojeno je istih pet komponenata kao i kod upitnika sa generalnom primenom, uz promenjen redosled drugog i trećeg faktora. Prvi faktor izdvojen iz upitnika CDMS-patike poklapa se sadržinski sa prvim faktorom iz generalnog upitnika i nosi naziv LOJALNOST BRENDU/PRODAVNICI. On objašnjava $17,4 \%$ varijanse rezultata $(\alpha=0,67)$. Poredak drugog i trećeg faktora je promenjen u odnosu na CDMS-generalni. Drugi izdvojeni faktor tako je SVEST O BRENDU i objašnjava 11,7\% varijanse rezultata $(\alpha=0,65)$. U ovom slučaju faktor je definisan sa jednom stavkom više („Zaista uživam u isprobavanju različitih proizvoda i marki”), koja je izbačena iz generalnog upitnika jer nije učestvovala u formiranju ovog niti bilo kojeg drugog faktora. Treći izdvojeni faktor objašnjava $10.5 \%$ varijanse rezultata $(\alpha=0,52)$ i nosi naziv PERFEKCIONIZAM. Stavke koje definišu ovaj faktor iste su kao i kod generalne primene. Četvrti izdvojeni faktor je IMPULSIVNOST i objašnjava $8,74 \%$ varijanse rezultata $(\alpha=0,46)$. Kao i kod drugog faktora, i ovde je broj stavki koje učestvuju u faktoru povećan sa dve na tri - dodata je stavka „Mislim da se različite marke kod proizvoda iste vrste ne razlikuju po kvalitetu", koja se u gornjem slučaju nalazi u faktoru Svest o vezi cena-vrednost. Peti faktor objašnjava $8,19 \%$ varijanse rezultata $(\alpha=0,26)$. Analogno generalnoj primeni, ovaj faktor se zove SVEST O VEZI CENA-VREDNOST. Umesto gore pomenute stavke koja se našla u četvrtom faktoru, u sastavu faktora se sada 
našla stavka „Kupujem brzo tako što kupim prvi proizvod koji mi se čini dovoljno dobrim", ali sa negativnim predznakom.

Kao i prethodnom slučaju, sve subskale beleže prilično nisku pouzdanost. Ipak, u upitniku koji se odnosi na patike pouzdanost je nešto viša za prve dve subskale koje se odnose na brendove. Najveći porast je zabeležen kod Svesti o brendu (0,65 naspram 0,47$)$, a nešto manji kod Lojalnosti brendu/prodavnici (0,67 naspram 0,61$)$. Takav rezultat je očekivan $s$ obzirom da je direkcija $u$ mišljenju jasnija kada je poznata kategorija proizvoda na koji se stavke odnose. Imajući u vidu proizvod - patike, ispitanici daju konzistentnije odgovore na stavke u okviru istog faktora.

Za razliku od generalnog upitnika gde je pronađena međusobna povezanost tri prva faktora, u slučaju sa patikama situacija je nešto složenija. Pored očekivane korelacije između dva faktora koji se odnose na brendove, Perfekcionizam se pokazao kao potpuno nezavisan. Svest o vezi cena-vrednost beleži negativne korelacije sa Lojalnošću brendu/prodavnici i Impulsivnošću. Ovaj nalaz je očekivan s obzirom da se stavke u faktoru Svest o vezi cena-vrednost pretežno ukazuju na traganje za rasprodajama i nižim cenama. Pretpostavka je da su to ponašanja koja isključuju lojalnost i impulsivnu kupovinu kada su patike u pitanju.

Tabela 7. Korelacije medu faktorima (CDMS-patike)

\begin{tabular}{lcccc}
\hline Faktori & $\begin{array}{c}\text { Lojal. brendu } \\
\text { /prodavnici }\end{array}$ & $\begin{array}{c}\text { Svest o } \\
\text { brendu }\end{array}$ & Perfekc. & Impulsiv. \\
\hline $\begin{array}{l}\text { Lojalnost brendu } \\
\text { /prodavnici }\end{array}$ & & & & \\
Svest o brendu & $\mathbf{. 2 2 ( . 0 0 )}$ & & & \\
Perfekcionizam & $-.05(.53)$ & $.11(.12)$ & & \\
Impulsivnost & $\mathbf{. 1 9 ( . 0 1 )}$ & $\mathbf{. 1 5 ( . 0 4 )}$ & $-.09(.21)$ & \\
Svest o vezi & $\mathbf{- . 1 9 ( . 0 1 )}$ & $-.01(.85)$ & $-.02(.78)$ & $\mathbf{- . 1 5 ( . 0 4 )}$ \\
cena-vrednost & -020 \\
\hline
\end{tabular}

\section{Diskusija}

Osnovni cilj istraživanja je bio provera faktorske strukture i pouzdanosti upitnika stilova donošenja kupovnih odluka CDMS, kao i testiranje njegove pouzdanosti prilikom primene u uslovima sa i bez vezanosti za proizvod. Krajnja svrha istraživanja je bila sticanje boljeg uvida u sam konstrukt kupovnih stilova. S obzirom da ovaj upitnik nije primenjivan na domaćoj populaciji, ovo is- 
traživanje potpomaže kros-kulturalnu validaciju konstrukta, mernog modela, ali i otvara vrata istraživanju kupovnog ponašanja u našoj sredini.

U oba slučaja, i kod generalne primene i kod vezanosti za proizvod, ekstrahovano je istih pet komponenata: Lojalnost brendu/prodavnici, Perfekcionizam, Svest o brendu, Impulsivnost i Svest o vezi cena-vrednost. Iako je primenjena originalna verzija upitnika CDMS koja je formirana na osnovu studije sprovedene u Nemačkoj i Velikoj Britaniji (Bauer, Sauer, \& Becker, 2006), izostala je očekivana četvorofaktorska struktura na kojoj se upitnik bazira.

Prvi izdvojeni faktor nosi isto ime kao i u pomenutoj studiji - Lojalnost brendu/prodavnici. Ipak, u prethodnoj studiji on je sadržinski obuhvatao još dva faktora (Perfekcionizam i Svest o brendu), koji su se sada samostalno izdvojili. Korelaciona analiza je pokazala da ova tri faktora zaista dele zajedničku varijansu, ali s obzirom da su se u većini prethodnih istraživanja javljali razdvojeno, takav nalaz možemo smatrati donekle očekivanim. Možemo reći da je postojanje tri separatne dimenzije bliže realnosti, s obzirom na prethodna istraživanja, ali i na činjenicu da su se ova tri faktora u našoj studiji razdvojila uprkos pretpostavljenoj strukturi upitnika u kojoj su spojeni. Svest o brendu i Perfekcionizam su se neizostavno javljali u svim dosadašnjim studijama, tako da njihovo identifikovanje nije iznenađenje. Sa velikom sigurnošću se može reći da njihovo postojanje treba pretpostaviti prilikom koncipiranja svake naredne verzije upitnika donošenja kupovnih odluka. Impulsivnost i Svest o vezi cenavrednost se nisu dosledno javljali tokom istorijata istraživanja upitnika CSI, ali u odnosu na studiju Bauera i saradnika su se sadržinski poklopili. Takav nalaz ukazuje na to da su dobro definisani u sadašnjem instrumentu.

Ekstrahovanjem navedenih pet faktora ova studija je učinila isto što i većina prethodnih: dala delimičnu potvrdu faktorske strukture stilova donošenja kupovnih odluka. Pozitivnu stranu istraživanja čini nalaz o kros-kulturalnoj konzistentnosti dobijenih faktora. To govori u prilog tezi da se u našoj zemlji mogu zabeležiti slični stilovi donošenja kupovnih odluka kao i u zemljama gde upitnici CSI i CDMS uveliko imaju svoju primenu. Podatak da su se identifikovani faktori prilično konzistentno javljali i u prethodnim studijama ide $\mathrm{u}$ prilog tome da se dobijeni upitnici nalaze na dobrom putu.

Osnovna mana upitnika koja su dobijena skraćivanjem upitnika CDMS je mali broj stavki - upitnik generalnih stilova je sastavljen od 14 stavki, a upitnik vezan za patike od 15. Jasno je da se iz tog kontingenta stavki ne može iznedriti više od pet faktora sa visokom pouzdanošću. Svih pet faktora je definisano malim brojem stavki (dve do četiri), što negativno utiče na pouzdanost subskala koje ih predstavljaju. Taj podatak svakako predstavlja ograničavajući fak- 
tor kada je u pitanju korišćenje upitnika u marketinškoj praksi. Rešenje za ovaj problem je dodavanje većeg broja stavki koje bi ove subskale uključivale, što je zadatak za naredna istraživanja. Iako prethodno pomenuti nalaz o kroskulturalnoj stabilnosti faktora predstavlja zasigurno argument za uvođenje instrumenata u praktičnu primenu kod nas, uslov za to ostaje da se izvrši proširenje po pitanju broja stavki po subskalama.

Ako se za identifikovane faktore sa određenom sigurnošću može tvrditi da zaista postoje (odnosno, predstavljaju kognitivne strukture merene pojave), pitanje je koji faktori su izostavljeni u novodobijenim upitnicima? Jedan od njih bi mogao biti faktor Rekreacijska i hedonistička kupovina, koji je izbačen iz koncepcije upitnika CDMS. S obzirom da je on identifikovan u doslovno svim prethodnim studijama, možemo reći da su ga autori upitnika CDMS (Bauer, Sauer, \& Becker, 2006) nepravedno zapostavili. Osnovni razlog za izbacivanje je bio to što su stavke koje ga opisuju uglavnom date u formi stava, a ne ponašanja. Svakako bi umesto izbacivanja bolje rešenje bilo preformulisati ih u ponašanja, s obzirom da ovaj faktor pokriva jedan važan set kupovnih stilova. Slično se može reći i za faktore Zbunjenost prevelikim izborom i Svest o novitetima i modnim trendovima, koji su takođe izbačeni iz upitnika CDMS. Iako postoje problemi sa konceptualizacijom ovih faktora, sadržaji na koje ukazuju govore $\mathrm{u}$ prilog tome da ti faktori mogu pokriti određene aspekte stilova donošenja kupovnih odluka. Svakako bi bilo poželjno uključiti ih u narednu verziju upitnika.

U prethodnim istraživanjima stilova donošenja kupovnih odluka pretežno su korišćeni uzorci studenata i mlađe populacije. Radi mogućnosti poređenja, i u ovoj studiji je korišćen uzorak mlade populacije. Ukoliko izađemo iz okvira nauke i vratimo se na osnovnu svrhu proučavanja ove pojave - omogućavanje praktične primene upitnika u marketinške i edukativne svrhe, jasno je da ograničavanje nalaza na ovu populaciju ne zadovoljava apetite marketinške prakse. Možda pionirskim pokušajima istraživanja ove pojave u našoj zemlji priliči da nalaze ograniči na određenu populaciju, ali zadatak za naredna istraživanja je primena upitnika na reprezentativnom uzorku odrasle potrošačke populacije.

Interesantan je nalaz da je praktično ista struktura identifikovana i u situaciji vezanosti za proizvod i nezavisno od njega. Dva su moguća objašnjenja za to. Prvo, moguće je da ispitanici prilikom popunjavanja generalnog CDMS imaju na umu proizvode koji su im veoma značajni, i daju praktično iste odgovore kao da im je zadat konkretan proizvod za koji su visoko involvirani. Drugo objašnjenje leži u kratkoj formi upitnika, koji možda nije uspeo da identifikuje razlike u ova dva slučaja. Postoji mogućnost da bi sa bogatijim setom stavki 
ove razlike došle do izražaja. $\mathrm{Na}$ osnovu toga, ostaje otvoreno pitanje da li je moguće formirati upitnik koji bi se odnosio na generalne stilove kupovine ili je potrebno praviti posebne upitnike za određene kategorije proizvoda? Iako je naša studija podarila jedinstveno rešenje za ove dve situacije, postoji opravdana sumnja da kupovina različitih kategorija proizvoda (i sa različitim nivoom involviranosti) angažuje različite kognitivne strukture. Drugim rečima, pretpostavka je da potrošači mogu imati različite stilove kupovine kada kupuju proizvode koji imaju lično značenje za njih u odnosu na one koji takvo značenje nemaju.

U uvodnom delu rada izneta je teza da je kros-kulturalna validacija upitnika stilova donošenja kupovnih odluka proces koji nikad neće dati uniformno rešenje. Složenost kupovnog ponašanja i, pre svega, njegova ovisnost o kulturalnim odlikama zajednica, specifičnostima tržišta roba u tim sredinama, potrošačkim potrebama, ekonomskoj moći i ukupnoj razvijenosti zajednica, umanjuju šanse da se identifikuju univerzalni kognitivni stilovi, barem ne tragom instrumenata kakvi su ovde primenjeni. Ipak, kreiranje verzije upitnika koja bi bila primenljiva na domaćoj potrošačkoj populaciji svakako nije nedostižno.

\section{Zaključak}

S obzirom da je rad pretežno psihometrijskog karaktera, može se reći da je ispunio zadati cilj, a to je provera faktorske strukture i pouzdanosti upitnika stilova donošenja kupovnih odluka CDMS u uslovima sa i bez vezanosti za proizvod. Značaj našeg istraživanja ogleda se u delimičnoj potvrdi faktorske strukture stilova donošenja kupovnih odluka koja je zabeležena u ranijim studijama. S druge strane, ipak je izostala očekivana četvorofaktorska struktura na kojoj se bazira primenjeni upitnik. I u slučaju generalne primene i kod vezanosti za proizvod ekstrahovano je istih pet komponenata: Lojalnost brendu/prodavnici, Perfekcionizam, Svest o brendu, Impulsivnost i Svest o vezi cena-vrednost. Nakon eliminacije određenog broja stavki iz upitnika, kreirana su dva upitnika: upitnik generalnih stilova donošenja kupovnih odluka sastavljen od 14 stavki i upitnik vezan za patike od 15 stavki. Oba upitnika se sastoje od pet subskala koje predstavljaju izdvojene faktore. Zabeležena je niska pouzdanost subskala u oba upitnika, što se delimično može pripisati malom broju stavki u njima.

Praktično ista struktura je identifikovana i u situaciji vezanosti za proizvod i nezavisno od njega, što ukazuje na to da ispitanici prilikom popunjavanja generalnog upitnika kupovnih stilova najverovatnije imaju na umu proizvode 
koji su im veoma značajni. Iako je naša studija podarila jedinstveno rešenje za ove dve situacije, postoji opravdana sumnja da kupovina različitih kategorija proizvoda angažuje različite kognitivne strukture.

Osnovne preporuke za naredna istraživanja odnose se na: dodavanje više stavki za postojeće subskale, uključivanje novih faktora u upitnik i primenu upitnika na drugim uzorcima.

\section{Literatura}

Bakewell, C., \& Mitchell, V-W. (2004). Male consumer decision-making styles. International Review of Retail, Distribution $\mathcal{E}$ Consumer Research, 14, 223-240.

Bauer H., Sauer, N., \& Becker, C. (2006). Investigating the relationship between product involvement and consumer decision-making styles. Journal of Consumer Behaviour, 5, 342-354.

Cowart, O., \& Goldsmith, R.E. (2007). The influence of consumer decisionmaking styles on online apparel consumption by college students. International Journal of Consumer Studies, 31, 639-647.

Fan, J.X., \& Xiao, J.J. (1998). Consumer decision-making styles of young-adult Chinese. The Journal of Consumer Affairs, 32, 275-94.

Hafstrom, J.L., Chae, J.S., \& Chung, Y.S. (1992). Consumer decision-making styles: comparison between United States and Korean young consumers. The Journal of Consumer Affairs, 26, 146-158.

Hui, A.S.Y., \& Siu, N.Y.M. (2001). Consumer decision-making styles in China: A cross-cultural validation. Asia Pacific Advances in Consumer Research, 4, 258-262.

Lastovicka, J. (1982). On the validation of lifestyle traits: A review and illustration. Journal of Marketing Research, 19, 126-138.

Lysonski, S., Durvasula, S., \& Zotos, Y. (1996). Consumer decision-making styles: A multi-country investigation. European Journal of Marketing, 30, 10-21.

Mitchell, V-W., \& Bates, L. (1998). UK consumer decision-making styles. Journal of Marketing Management, 14, 199-225.

Mitchell, V-W., \& Walsh, G. (2004). Gender differences in German consumer decision-making styles. Journal of Consumer Behaviour, 3, 331-346.

Moschis, G.P. (1976). Shopping orientations and consumer use of information. Journal of Retailing, 52, 61-70.

Petrović I., i Kovačević, P. (1996). Merenje involviranosti potrošača. Psihologija, 1, 71-82. 
Shim, S. (1996). Adolescent consumer decision-making styles: the consumer socialization perspective. Psychology \& Marketing, 13, 547-569.

Sproles, G.B., \& Kendall, E. (1986). A methodology for profiling consumers decision-making styles. Journal of Consumer Affairs, 20, 267-279.

Walsh, G., Mitchell, V-W., \& Hennig-Thurau, T. (2001). German consumer decision-making styles. Journal of Consumer Affairs, 35, 73-95.

Wang, CL., Siu, N.Y.M., \& Hui, A.S.Y. (2004). Consumer decision-making styles on domestic and imported brand clothing. European Journal of Marketing, 38, 239-252. 


\title{
VALIDATION OF METRIC CHARACTERISTICS OF CONCUMER DECI- SION-MAKING STYLES QUESTIONNAIRE APLLIED GENERALY AND WHEN RELATED TO SPECIFIC PRODUCT
}

\author{
Predrag Okanović, Dragana Okanović, Nebojša Majstorović
}

The main aim of this research is validation of factor structure of consumer decision-making styles questionnaire CDMS, as well as testing its reliability when applied generaly and related to specific product. The later modifications of consumer decision-making styles researches in scope of consumer characteristics approach comprise theoretical background of this research. This approach considers existing of stable traits which are related to decision-making processes during shopping. This is the first time that CDMS questionniare has been applied in Serbia with the aim of cross-cultural validation. Two versions of the instrument were applied to two separated samples of young highly educated people - general consumer style questionnaire $(\mathrm{N}=200)$ and questionnaire related to specific product $(\mathrm{N}=230)$. Previuos to application of the second questionnaire, the product for which the participants had showed high involvement was chosen. These were sport shoes, so the content of the second qusetionnaire was related to sport shoes.

This study has given partial confirmation of factor structure of this questionnaire. In both cases, general and product-related, five components were extracted: brand/store loyalty, perfectionism, brand conciousness, impulsiveness and price-value conciousness. Two questionnaires were created after the elimination of some items: general decision-making style questionnaire which consisted from 14 items and sport shoes related qusetionnaire with 15 items. Both questionnaires have five subscales which represent exstracted factors. Low reliability of subscales was recorded, which partially can be explained with small number of items. Some general recommendations for further researches point out to: adding more items to exisitng subscales, including new factors in questionniare and application of this questionnaire on different samples.

Key words: consumer decision making styles, consumer styles questionnaire, psychometric characteristics 